\title{
ENVIRONMENTAL MANAGEMENT OF ISO 14001 SYSTEM ENFORCEMENT IN EU COUNTRIES
}

\author{
Elżbieta Zębek*
}

\begin{abstract}
The European Union International Organization for Standardization management system for the environment (ISO 14001) is established by European Commission Regulation 1221/2009. This legislates a voluntary system where organizations can register in a community eco-management and audit scheme. In the literature, this standard is recognized as an instrument of international environmental protection law, introduced by soft law regulations. ISO 14001 has been implemented by many global and European organizations, and it strives to improve the quality of their environmental resources.

It was considered that the ISO 14001 eco-management and audit scheme enforced protection of environment in EU countries by imposing the obligation to implement appropriate legal regulations in this area. This article aims is determine what legal solutions in chosen UE countries enable the effective implementation of ISO 14001 and what positive effects it has on the state of the environment in these countries.

The results demonstrated that the number of certified organizations is increasing despite the many difficulties and costs of implementing and organizing required environmental protection areas. The implementation of ISO 14001 was described using the example of Poland and Italy compared to other EU countries. The uptake identifies improved environmental quality, and this is confirmed by indicators of decreasing gas emissions and increasing waste recycling which improve global
\end{abstract}

\footnotetext{
Dr. habil. Elżbieta Zębek, Associate Professor, Faculty of Law and Administration, Department of International Public Law and Law of European Union, University of Warmia and Mazury in Olsztyn; correspondence address: Obitza 1, 10-752 Olsztyn, Poland; e-mail: elzbieta.zebek@uwm.edu.pl; https://orcid.org/0000-0002-8637-8391.
} 
air, soil and water quality. The higher implementation index of the ISO 14001 standard in Italy translates into higher environmental quality indicators in this country than in Poland.

Keywords: EU, Environmental management, ISO 14001, Enforcement, Environmental status

\section{INTRODUCTION}

The European Union (EU) is a supra-national organization which currently devotes a lot of time to environmental protection in accordance with the principle of sustainable development. The importance of business responsibility for environmental conditions has increased with expanded use of natural resources and increased degraded pollutant emissions, and the effectiveness of an organization's environmental protection is measured by the extent of their responsible behavior. Moreover, the EU's introduction of more stringent environmental regulations has forced economic entities to implement environmental management systems to meet the higher prescribed quality standards ${ }^{1}$. Industrial adherence to these regulations will improve environmental quality and promote economic development in line with the principles of sustainable development. In addition, the 1972 Stockholm Declaration decrees that sustainable development should combine human rights with environmental and economic law and this is reflected in the preamble: "For the purpose of attaining freedom in the world of nature, man must use knowledge to build, in collaboration with nature, a better environment. To defend and improve the human environment for present and future generations has become an imperative goal for mankind-a goal to be pursued together with, and in harmony with, the established and fundamental goals of peace and of worldwide economic and social development". At the 1992 conference in Rio de Janeiro, the relationship between environmental deterioration and economic development was demonstrated. At the same time, the right to

1 Krislin Kivi, and Natalja Gurvits, "Eco-Management and Audit Scheme (EMAS) implementation in the European Union: survey of Estonian certified organisations," European Integration Studies 11 (2017): 215, http:// 10.5755/j01.eis.0.11.17982. 
development was indicated, taking into account the environmental needs of present and future generations ${ }^{2}$. This is also reflected in EU environmental policy, especially in Article 191 TFEU, which defines the objectives and principles of this policy. These include: 1) preservation, protection and improvement of the quality of the environment; 2 ) protection of human health; 3) careful and rational use of natural resources; 4) promoting measures at the international level to deal with regional or worldwide environmental problems, in particular combating climate change; 5) a high level of protection taking into account the diversity of situations in different regions of the $\mathrm{EU}^{3}$. The above implies the need to apply appropriate legal instruments in environmental protection in conditions of sustainable development, also addressed to entities conducting business activity.

According to J. Ciechanowicz-McLean, the use and importance of economic instruments of environmental protection law is currently increasing, which indirectly affect the activities of entities obliged to protect the environment, i.e. marketable licenses, insurance or pro-ecological management systems ${ }^{4}$. Environmental management systems are classified as legal instruments aimed at environmental protection and the addressees are enterprises 5 . Such instruments include ISO quality management and environmental management standards.

Analyzing the legal nature of the ISO standard, it can be concluded that they are not legislative acts in terms of jurisprudence, but fulfill the criteria of normative acts as norms created outside the state apparatus and subject to limited binding force, addressed to members of their organizations $s^{6}$. Thus, the ISO standards in the field of quality and environmen-

2 See more: Janina Ciechanowicz, Międzynarodowe prawo ochrony środowiska (Warsaw: PWN, 1999), 30; Zbigniew Bukowski, Prawo międzynarodowe a ochrona środowiska (Toruń: Dom Organizatora, 2005), 90.

3 Maria M. Kenig-Witkowska, Prawo środowiska Unii Europejskiej (Warsaw: Lex a Wolters Kluwer business, 2012), 20.

4 Janina Ciechanowicz-McLean, and Tomasz Bojar-Fijałkowski, ed. Gospodarcze prawo środowiska (Gdańsk: Wydawnictwo Uniwersytetu Gdańskiego, 2009), 7.

5 Janina Ciechanowicz-McLean, Prawo ochrony i zarzadzania środowiskiem. 2nd ed. (Warsaw: Difin, 2019), 52.

6 Jolanta Jabłońska-Bonca, Wstęp do nauk prawnych (Poznań: Ars Boni Et Aequi, 1996), 37-42. 
tal management are normative acts of statutory law with binding force directed towards addressees, who are voluntary members of the organization constituting this act, thus taking their place in the legal system. Environmental management is regulated by the norms of environmental law with the use of all available administrative and legal instruments ${ }^{7}$. In the EU, the legal definition of an environmental management system is included in article $2(\mathrm{k})$ of the Regulation (EC) No $761 / 2001^{8}$, means the part of the overall management system that includes the organizational structure, planning activities, responsibilities, practices, procedures, processes and resources for developing, implementing, achieving, reviewing and maintaining environmental policy? The environmental management system is one of the indirect instruments of environmental law, and at the same time is responsible for the implementation of environmental objectives ${ }^{10}$. The ISO standard serves to strengthen the environmental protection at the level of the enterprise through voluntary self-control. The aim is to improve the ecological activity of various entities and to harmonize national standards related to environmental management ${ }^{11}$.

The European Union International Organization for Standardization ISO 14001 is the most formal standard for eco-management in EU countries. ISO 14001 contains standards and guidelines for both environmen-

7 Tomasz Bojar-Fijałkowski, "Elementy zarządzania jakością i zarządzania środowiskowego wspomagające nowe zarządzanie publiczne w administracji," in Pomiędzy zarzadzaniem publicznym a ogólną teoria administracji, ed. Ewa Jasiuk, Gerard P. Maj, Kamil Sikora, and Stanisław Wrzosek (Radom: Wydawnictwo WSH, 2013), 134, 136.

8 Regulation (EC) No 761/2001 of the European Parliament and of the Council of 19 March 2001 allowing voluntary participation by organisations in a Community eco-management and audit scheme (EMAS) (OJ L 114, 24.4.2001, p. 1-29).

9 See more: Tomasz Bojar-Fijałkowski, "Wykonanie Rozporządzenia (WE) 761/2001 przez organy administracji publicznej w Polsce," in Finansowanie zadan administracji publicznej ze środków UE, ed. Marcin Szewczak, and Małgorzata Ganczar (Lublin: Wydawnictwo KUL, 2001), 9-20.

10 Tomasz Bojar-Fijałkowski, “Ocena skuteczności zarządzania środowiskowego jako instrumentu prawa ochrony środowiska na przykładzie EMAS,” in Dekada harmonizacji w prawie ochrony środowiska, ed. Maciej Rudnicki, Anna Haładyj, and Kamila Sobieraj (Lublin: Wydawnictwo KUL, 2011), 230.

11 Janina Ciechanowicz-McLean, Ochrona środowiska $w$ dziatalności gospodarczej (Warsaw: LexisNexis, 2003), 145-146. 
tal management and technological norms that support existing organization functions such as auditing. These standards relate to "monitoring an organization's activities to minimize harmful effects on the environment caused by its production activities that pollute or deplete natural resources"12. Therefore, environmental management is a process carried out by an organization within itself, aimed at minimizing its impact on all elements of the environment based on obligatory standards, identified with sectoral environmental protection law, as well as voluntary ones, e.g. regulating environmental management systems occurring in the organization itself according to the rules and under the control of administrative authorities ${ }^{13}$.

ISO 14001 defines the criteria for an environmental management system which can be certified, and it defines the framework that a company or organization should apply to create an effective environmental management system. In addition, ISO 14001 implementation and application guarantees the company management and employees that the environmental impact of their operations is monitored and that the state of their resources is improved ${ }^{14}$. Eco-management system included ISO 14001 was introduced by the European Parliament and Council Resolution

12 James H. McCreary, "ISO 14001 A framework for coordinating existing environmental management responsibilities," CIM Bulletin 89 (1996): 824; Lighthouse Consulting, "Summary of ISO 14000," Coastal Resources Center, University of Rhode Island, 2003, accessed February 23, 2019, https:/www.crc.uri. edu/download /12_ISO_14000_ Summary_ok.pdf.

13 Tomasz Bojar-Fijałkowski, "Nauka o zarządzaniu w gospodarczym prawie ochrony środowiska - analiza wybranych pojęć," in Zasada zrównoważonego rozwoju w wymiarze gospodarczym i ekonomicznych, ed. Bartosz Rakoczy, Karolina Karpus, Małgorzata Szalewska, and Martyna Walas (Toruń: Wydawnictwo UMK, 2015), 205; Tomasz Bojar-Fijałkowski, “Odpowiedzialność prawna organizacji z certyfikowanym systemem EMAS," in Odpowiedzialność za środowisko w ujęciu normatywnym, ed. Elżbieta Zębek, and Michał Hejbudzki (Olsztyn: Wydawnictwo UWM, 2017), 236.

14 See: European Commission, "EU Ecolabel indoor cleaning services Commission Decision (EU) 2018/680," September 2018, accessed February 23, 2019, http: Artyku1\%20 EMAs/ normy\%20EMAS\%20i\%20ISO/180525_User\%20 Manual_Ecolabel\%20indoor\%20cleaning\%20services\%20 september\%202018.pdf; ISO, "Popular standards ISO 14000 family, Environmental management," 2018, accessed February 23, 2019, https:// www.iso.org /iso-14001-environmental-management.html. 
No. $1221 / 2009^{15}$. The targeted organizations especially included financial institutions, schools, service providers and manufacturing companies which wished to limit negative environmental effects through humanitarian desire and without external legal obligation ${ }^{16}$. This system specified its expectations by nominating the following sectors: retail trade, tourism, construction, food and beverage manufacturing, agriculture, public administration, car manufacturing, electrical and electronic equipment manufacturing, waste management, telecommunications and the manufacture of metal products ${ }^{17}$.

It was considered that the ISO 14001 eco-management and audit scheme enforced protection of the environment in EU countries by imposing the obligation to implement appropriate legal regulations in this area. The implementation of ISO 14001 was described on the example of Poland and Italy compared to other EU countries. The following research hypothesis was formulated: what legal solutions in these countries enable the effective implementation of ISO 14001 and what positive effects it has on the state of the environment in these countries? This article uses the dogmatic-legal and comparative-law methods. Examined was the effectiveness of ISO 14001 enforcement for EU countries' environmental improvement by analyzing the legal regulations, literature and available statistical data on the different ISO 14001 implementation methods and the environmental state in these countries.

15 OJ L 342, 22.12.2009, p. 1-45.

16 See: George Balan, and Laris Dragolea, "Implementation of environmental management systems - ISO 14001 or EMAS," Academic Research International 4(3) (2013).

17 Patricia Tourais, and Nuno Videira, "Why, How and What do Organizations Achieve with the Implementation of Environmental Management Systems? - Lessons from a Comprehensive Review on the Eco-Management and Audit Scheme," Sustainability 8(3) (2016): 283, https://doi.org/10.3390/su8030283; European Commission, "EMAS - key benefits for organisations and authorities," EMAS scheme in Slovenia, Ljubljana, 14 September 2017, accessed February 23, 2019, http://Artyku1\%20EMAs/ normy\%20EMAS\%20i\%20ISO/2_delavnica\%20 EMAS_PAQUOT_14sept2017.pdf. 


\section{MAIN ASSUMPTIONS AND LEGAL BASIS OF THE ISO 14001 \\ ENVIRONMENTAL MANAGEMENT STANDARD IN THE EU}

Environmental system management is mainly determined by European Commission (EC) Regulation No 1221/2009 which establishes a voluntary system allowing organizations to register in a community international eco-management and audit scheme (ISO). The objective is to promote continuous improvement in the environmental performance by implementing environmental policies, programs and management systems and their regular audit. Further important aims are to provide the public with additional information on the environmental performance of participating sites and to encourage active employee involvement in the establishment of environmental management systems ${ }^{18}$.

The ISO 14001 standards are based on the Deming cycle which inspired the "Plan-Do-Check-Act" movement. This principle enables organizations to continuously improve associated environmental outcomes by harmonizing ${ }^{19}$;

(1) Planning the environmental aspects under legal requirements, environmental policy, objective and targets;

(2) Doing; by following the action plan which considers resources and responsibilities, employee involvement, communication and reporting;

(3) Checking by monitoring the results and recording the audit, evaluation and compliance results;

(4) Acting, through continuous management assessment of environmental performance.

The initial planning phase defines the processes required to deliver the best possible results. This is followed by implementing the activities in the planned procedures, checking plan efficiency and identifying the areas

18 Alfred M. Farmer, ed., Manual of European Environmental Policy (London: Routledge, 2012), 934.

19 See more: Francesco Testa, Fabio Iraldo, and Tiberio Daddi, "The Effectiveness of EMAS as a Management Tool: A Key Role for the Internalization of Environmental Practices," Organization \& Environment 31(1) (2017): 52, https://doi.org/ $10.1177 \% 2 \mathrm{~F} 1086026616687609$. 
that require improvement. The final stage then sets new goals in a revised environmental plan ${ }^{20}$.

Adherence to EU Regulation No 1221/2009 demands determination of the organization's current environmental management system. This should include; (1) a description of all direct and indirect activities which result in significant environmental impact; (2) environmental objectives and targets currently in place and (3) a summary of the effectiveness of the set objectives and targets. The collected data will enable annual comparison of environmental performance and determine areas that need improvement. This Regulation then emphasizes the requirements for implementing environmental policies, programs and management systems. These include auditing the accreditation and functioning of environmental verifiers, and also the information that must be provided to the ISO14001 and EMAS bodies. Annex II part B of this Regulation stresses the required environmental reviews, legal compliance, environmental performance, employee involvement and communication aspects. This is complemented by Article 19 which specifies that the environmental verifier must validate updated information in the environmental statement at least on an annual basis ${ }^{21}$.

EC Regulation 196/2006 22 is the most important legislation for ISO 14001 implementation. This regulation amended Annex I in EC Regulation 761/2001 to reflect ISO Standard 14001:2004 and it repealed Decision $97 / 265 / \mathrm{EC}$ on the recognition of ISO 14001:1996. These changes were made to ensure consistency in environmental management system requirements. Annex I stated "organizations participating in the EMAS eco-management and audit scheme (EMAS) shall implement the require-

20 Piotr Pachura, and Agnieszka Ociepa-Kubicka, "Management and audit scheme (EMAS) functioning on the example of the water supply and sewerage joint stock company of the Częstochowa District,” Polish Journal of Management Studies 10(2) (2014): 148.

21 Commission Regulation (EU) 2017/1505 of 28 August 2017 amending Annexes I, II and III to Regulation (EC) No 1221/2009 of the European Parliament and of the Council on the voluntary participation by organisations in a Community eco-management and audit scheme (EMAS) (Text with EEA relevance) (OJ EU L 222/1 29.8.2017).

22 Commission Regulation (EC) 196/2006 of 3 February 2006 amending Annex I to Regulation (EC) 761/2001 of the European Parliament and of the Council to take account of the European Standard EN ISO 14001:2004, and repealing Decision 97/265/EC (OJ L 32/4). 
ments of EN ISO 14001:2004 which are described in Section 4 of the European Standard". This annex legislated that environmental management system requirements included the general requirements, environmental policy, planning, implementation and operation, control of documents and checking and management review. The general requirements included "the organization shall establish, document, implement, maintain and continually improve an environmental management system in accordance with the requirements of this International Standard and determine how it will fulfil these requirements". The organization must define the scope and policy of their environmental management. This should therefore be "(a) appropriate to the nature, scale and environmental impacts of its activities, products and services; (b) include a commitment to continual improvement and prevention of pollution; (c) include a commitment to comply with applicable legal requirements and with other requirements to which the organization subscribes which relate to its environmental aspects; (d) provide the framework for setting and reviewing environmental objectives and targets; (e) be documented, implemented and maintained; (f) communicated to all persons working for or on behalf of the organization and (g) is available to the public".

Organizations should identify the legal obligations and the environmental aspects of their activities, products and services within the defined scope of the environmental management system that it can control, and also those that it can influence in planned and new developments and new or modified activities, products and services. This will establish the aspects that have or can have significant impact on the environment. Legally, "the organization shall establish, implement and maintain documented environmental objectives and targets, at relevant functions and levels within the organization. The objectives and targets shall be measurable, where practicable, and consistent with the environmental policy, including the commitments to prevention of pollution, to compliance with applicable legal requirements and with other requirements to which the organization subscribes, and to continual improvement". The environmental system management should also include human resources and specialized skills, organizational infrastructure, technology and financial resources. The legislation further requires that "the organization shall ensure that any person(s) performing tasks for it or on its behalf that have the potential 
to cause a significant environmental impact(s) identified by the organization is (are) competent on the basis of appropriate education, training or experience, and shall retain associated records. The organization shall provide training in the range of environmental aspects and its environmental management system. The organization shall establish, implement and maintain procedures to make persons working for it or on its behalf aware of: (a) the importance of conformity with the environmental policy and procedures and with the requirements of the environmental management system; (b) the significant environmental aspects and related actual or potential impacts associated with their work, and the environmental benefits of improved personal performance; (c) their roles and responsibilities in achieving conformity with the requirements of the environmental management system; and (d) the potential consequences of departure from specified procedures".

The evolution of the Environmental Management System and ISO 14001 had three stages. The ISO 14001:1996 first phase involved the overall organizational structure and management system with planning activities, responsibilities, practises, procedures and resources for developing, implementing, achieving and maintaining environmental policy. The ISO 14001:2004 second stage was targeted at the actual management system procedures used in developing and implementing its environmental policy and the management of the organization's individual environmental aspects. The final ISO 14001:2015 phase focused on changing and managing the relevant environmental protection procedures, and then fulfilling compliance obligations, addressing ongoing risks and recognizing opportunities for improvement ${ }^{23}$. The ISO 14001:2015 scope covers the management outcomes expected in enhanced environmental performance, fulfilled compliance obligations and achievement of environmental objectives. The major objectives were a planned $20 \%$ reduction in production energy use within 4 years, $100 \%$ recycling of paper and plastic waste before 2017 and the elimination of persistent organic pollutant emissions by the end of $2016^{24}$. The intended planning should therefore comply with

23 Martin Abraham, Sustainable Technologies (Amsterdam: Elsevier, 2017), 24-25.

24 European Commission, "Communication from the Commission to the European Parliament, the Council, the European Economic and Social Committee and the Committee of 
legal obligations, combat threatening risks in the individual production processes and seek and create opportunities for beneficial environmental outcomes. The product life cycle and all service procedures must be considered in planning interventions, and these may require a complete overhaul. It is essential to monitor the consecutive and interlinked stages from raw material acquisition and generation from natural resources to their final disposal ${ }^{25}$. Important company benefits certified by ISO 14001 include: (a) conformance with legislative and regulatory requirements; (b) minimized risk of regulatory and environmental liability; (c) improved efficiency and reduced resource consumption and waste; (d) less energy consumption; (e) reduced costs for emissions, discharges, waste handling, transport and disposal; (f) increased competitive advantage by demonstrating environmental commitment and (g) improved company image through a solid foundation of improved relationships with customers, investors, regulators and the broader community ${ }^{26}$.

The main reason companies decided to implement the ISO 14001 system was the customer and contractor expectation and requirement of this standard. The following five key principles were instrumental in ISO 14001 adoption; (1) environmental policy, (2) planning, (3) implementation, (4) action and (5) checking and reviewing the management system while focusing on continuous improvement ${ }^{27}$. Authors have indicated the following motivating forces for ISO 14001 implementation;

the Regions", A European Strategy for Plastics in a Circular Economy\{COM(2018)28final\}, Brussels, 16.1.2018SWD(2018) 16 final; European Commission, "A European Strategy For Plastics in a Circular Economy," accessed March 23, 2019, https://ec.europa.eu/environment/ circular -economy /pdf/plastics-strategy-brochure.pdf.

25 Stefan Larsson, "ISO 14001:2015, Six Dimensions of Sustainability," 2015, accessed March 21, 2019, http:/artykuł\%20EMAs/normy\%20EMAS\%20i\%20ISO/201512-02-Stefan-Larsson.pdf.

26 "ISO 14001 Environmental Management Systems Training, Audit \& Certification Services," 2018, accessed March 25, 2019, www.saiglobal.com/assurance.

27 See: Inaki Heras-Saizarbitoria, ed., ISO 9001, ISO 14001, and New Management Standards (Cham: Springer International Publishing, 2018), 98, https://doi. org/10.1007/978-3-319- 5675-5; Evangelos Psomas, Christos V. Fotopoulos, and Dimitrios P. Kafetzopoulos, "Motives, difficulties and benefits in implementing the ISO 14001 Environmental Management System," Management of Environmental Quality An International Journal 22(4) (2011): 511, https://doi.org/10.1108/14777831111136090. 
(1) the response to pressure from external stakeholders; (2) pro-action and anticipation of future business problems; (3) legal problems and (4) internal influences. Motivation is also inspired by the ISO 14001 certification of environmental responsibility which commands respect in international markets and provides competitive advantage. Barriers to obtaining this certificate include companies' anti-environmental policy, involved costs and the protection of its trade-mark and resources despite employee desire to protect the environment. Companies with this certificate acknowledged that the greatest difficulties in obtaining the ISO 14001 certificate were defining appropriate environmental goals and the methods of measuring environmental improvement. This knowledge is most important because the identification of environmental aspects is an essential factor in determining the effort needed to implement the standard. There is also the additional difficulty of the lack of human resources, rather than finances, in operating the environmental protection system. This interrupts the implementation process and resources are then redirected to core business operation $^{28}$. Authors have also reported that some firms fail to satisfy all legal environmental provisions in their operations and can therefore incur administrative or judicial sanctions of fines and damages to plaintiffs. The inadvertent discovery of existing regulatory violations can also prevent companies from considering ISO 14001 implementation. Any potential advantage is counteracted by strict auditing of unknown extent, and the company may feel threatened by the possibility of having to defend charges of negligence, failure of disclosure or intent of non-compliance ${ }^{29}$.

28 Evangelos Psomas, Christos V. Fotopoulos, and Dimitrios P. Kafetzopoulos, "Motives, difficulties and benefits in implementing the ISO 14001 Environmental Management System," Management of Environmental Quality An International Journal 22(4) (2011): 516, https://doi.org/10.1108/14777831111136090; Paula C. Murray, “The international environmental management standard, ISO 14000: a non-tariff barrier or a step to an emerging global environmental policy?," Penn Law: Legal Scholarship Repository 18(2) (2014): 579; Aline Vomero Reisa, Fabio de Oliveira Nevesa, Suzana Eda Hikichia, Eduardo Gomes Salgadoa, and Luiz Alberto Beijoa, "Is ISO 14001 certification really good to the company? a critical analysis," Production Systematic Review 28 (2018), https://doi. org/10.1590/0103-6513.20180073.

29 Raymond C. Wilson, "What you don't know can definitely hurt you," Pollution Engineering 30(12) (1998): 33-34. 
European Commission data reveals that Europe had 105,534 organizations with ISO 14001 certification in 2012, and this contrasted with 285,844 globally. European countries also have ISO 14001 implementation growth rates, where Spain and Italy recorded the highest certification increase in $2012^{30}$. The ISO recorded 301,647 certificates issued to 171 countries by December 2013 (available at https://www.iso.org/ the-iso-survey.html). The five major industry sectors involved were: (1) 40,430 construction companies (2) 24,791 raw and finished metal products (3) 22,663 electrical and optical equipment (4) 15,516 wholesale and retail trade and motor vehicle repair and (5) 12,957 rubber and plastic product companies. In contrast, EMAS registered approximately 4,000 organizations and over 9,000 enterprises in $2017^{31}$. The data show that Italy, Spain and The United Kingdom had the highest number of ISO 14001 registered organizations in 2012, while Poland had the average number of approximately 2,000. Further analysis of the average European certificate growth rate highlighted approximately 13\% growth between 2005 and 2012. In addition, the 2012 ISO Central Secretariat Survey reported that services are aggregated as a single sector. This service group comprises the highest number of ISO 14001 certifications and it includes hotels, restaurants, transport, storage and communication, engineering services and education and public administration ${ }^{32}$.

30 European Commission, "Final Report Supporting the Evaluation of the Implementation of EMAS," June, 2015, accessed March 28, 2019, http:/Artyku1\%20EMAs/ normy\%20EMAS\%20i\%20ISO/30752634-549a-11e7-a5ca-01aa75ed71a1.en.pdf.pdf.

31 European Commission, "EMAS - key benefits for organisations and authorities," EMAS scheme in Slovenia Ljubljana, September 14, 2017, accessed March 25, 2019, http:// Artykuł\%20EMAs/normy\%20EMAS\% 20i\%20ISO/2_ delavnica\%20EMAS_PAQUOT_ 14sept2017.pdf; See: Luis M. Ciravegna, and Martins da Fonseca, "ISO 14001:2015: An Improved Tool for Sustainability," Journal of Industrial Engineering and Management 8(1) (2015): 42, http://dx.doi.org/10.3926/jiem.1298.

32 European Commission, "Final Report Supporting the Evaluation of the Implementation of EMAS," June, 2015, accessed March 26, 2019, http:/Artyku1\%20EMAs/ normy\%20EMAS\%20i\%20ISO/30752634-549a-11e7-a5ca-01aa75ed71a1.en.pdf.pdf. 


\section{IMPLEMENTATION OF ISO 14001 IN THE LEGAL SYSTEM OF CHOSEN EU COUNTRIES}

The analysis of the implementation of the ISO 14001 standard was carried out using the example of Poland and Italy with an average and high index of implementation of this standard by the organization and enterprises. The group of ISO 14001 standards in Poland is a collection of several standards related to environmental management. Some of the international standards have been implemented in the Polish legislation. Poland implemented the standard earlier ISO 14001:2004 ${ }^{33}$, which defined the criteria necessary to be met by the organization applying for the certificate. The certification procedure may be carried out only by an accredited inspection body, the competences and powers of which in this regard are determined by national law ${ }^{34}$ - The Polish Center of Accreditation. Initially, the certification body carries out an initial audit including a documentation review, assessment of the appropriateness of the selection and description of environmental aspects. Compliance with applicable law, the implementation of environmental policy and the principles of continuous improvement established by the organization are subject to control. After the initial procedure, the certifying audit starts to check the compliance of the organization's procedures with the provisions of the standard. The most important issues covered by the control include the method of identifying aspects and the implementation of environmental objectives and tasks, as well as corrective and preventive actions in this regard. After detecting and correcting any shortcomings and non-conformities, the auditor recommends the certification body to issue an environmental man-

33 Based on the document: "ISO14001: 2004 Environmental management systems, requirements and guidelines for use."

34 Currently obliged the Act of 13 April 2016 on conformity assessment and market surveillance systems (LJ of 2019, item 544 as amended), which implemented the provisions of the Regulation (EC) No 765/2008 of the European Parliament and of the Council of 9 July 2008 setting out the requirements for accreditation and market surveillance relating to the marketing of products and repealing Regulation (EEC) No 339/93 (OJ L 218, 13.8.2008, p. 30-47). 
agement system certificate for the audited organization. The validity of such a certificate is usually 3 years ${ }^{35}$.

In September 2015, the new ISO 14001: 2015 standard was issued. The transition period for adapting the environmental management system to the new requirements was 3 years. The new standard places even greater emphasis on environmental protection and, within this framework, on proactive initiatives. The key change in the new edition is the inclusion of the risk management requirement in the environmental management system. The implementation of ISO 14001: 2015 can also lead to savings by improving the efficiency and productivity of the organization. The way to do this is to identify approaches to reduce waste, optimize the consumption (costs) of raw materials and utilities, reduce losses, etc. This standard contains more detailed requirements for the process approach based on the identification of environmental risk types, introduces requirements for the life cycle of goods and services and the supply chain, among others by new requirements for suppliers and the provision of environmental information to product recipients, as well as abolishing the obligation to create a procedure for the identification of environmental aspects (maintaining the requirement of identification only). Before starting the implementation of the updated standard, it is necessary to identify the areas in the management system (the so-called gaps) necessary for the implementation of new elements of the standard. The task of this stage is to identify the areas and processes necessary to update or change the organization so as to obtain full compliance with the new requirements. Examples of identified environmental aspects in the ISO 14001: 2015 system are as follows: emission of pollutants into the air from transport and production processes, biological imbalance, domestic and technological sewage, harmfulness to human and animal health, odor emission, water consumption and energy, hazardous substances, municipal and hazardous waste. The organization applying for this standard must demonstrate that its ac-

35 See: Tomasz Bojar-Fijałkowski, "System ISO 14001 jako instrument międzynarodowego prawa ochrony środowiska," Europejski Przegląd Prawa i Stosunków Międzynarodowych 4(19) (2011): 54-56. 
tivities comply with environmental legislation ${ }^{36}$. The list of legal acts in the field of environmental protection (not a closed catalog), the activities of which must be compliant on the day of the ISO 14001 zero audit, include: 1) acts on general principles of environmental protection law, water law, maintenance of cleanliness and order, water supply and sewage disposal, waste and packaging management, ozone-depleting substances, greenhouse gas management system, chemicals, waste electrical and electronic equipment $^{37}$, 2) executive regulations ${ }^{38}$ to these acts and EU regulations ${ }^{39}$.

36 The requirements are included in the document: PN-EN ISO 14001: 2015-09 "Environmental management systems - Requirements and guidelines for use."

37 Act of 27 April 2001 Environmental Protection Law (LJ of 2020, item 1219 as amended), Water Law of 20 July 2017 (LJ of 2020, item 310), Act of 13 September 1996 on maintaining cleanliness and order in municipalities (LJ of 2020, item 1439), Act of 7 June 2001 on collective water supply and collective discharge wastewater (LJ of 2019, item 1437 as amended), Act of 14 December 2012 on waste (LJ of 2020, items 797, 875), Act of 13 June 2013 on the management of packaging and packaging waste (LJ of 2020, item 1114), the Act of 15 May 2015 on substances that deplete the ozone layer and on certain fluorinated greenhouse gases (LJ of 2019, item 2158 as amended), the Act of 17 July 2009 on the system for managing the emissions of greenhouse gases and other substances (LJ of 2020, item 1077), the Act of 25 February 2011 on chemical substances and their mixtures (LJ of 2019, item 1225 as amended), the Act of 11 September 2015 on waste electrical and electronic equipment (LJ of 2019, item 1895).

38 The scope of the regulations of the ordinances covers, inter alia: substances particularly harmful to the aquatic environment; conditions for discharging sewage into water or soil; waste catalog; acceptable methods of their recovery; dealing with waste oils; emission standards for installations, fuel combustion sources and waste incineration or co-incineration devices; the scope of information contained in the report to the National Database on emissions of greenhouse gases and other substances; fees for using the environment; packaging labeling patterns; minimum annual recovery and recycling levels for multi-material packaging and for hazardous substance packaging; permissible levels of electromagnetic fields in the environment; reports on ozone-depleting substances or fluorinated greenhouse gases; the categories of dangerous substances; types and quantities of hazardous substances present in the plant, which determine the classification of the plant as an plant with an increased or high risk of a serious industrial accident; the requirements to be met by a safety report on a high-risk establishment.

39 Regulation (EC) No 842/2006 of the European Parliament and of the Council of 17 May 2006 on certain fluorinated greenhouse gases (OJ L 161, 14.6.2006, p. 1-11); Regulation (EU) No 517/2014 of the European Parliament and of the Council of 16 April 2014 on fluorinated greenhouse gases and repealing Regulation (EC) No 842/2006 (OJ L 150, 20.5.2014, p. 195-230), Regulation (EC) No 1005/2009 of the European Parliament 
The ISO 14001: 2015 environmental management system must be formally established, documented, implemented, maintained and improved. According to the guidelines, this standard must meet the following requirements: 1) description and implementation of the documentation supervision procedure; 2 ) identifying and planning operations that are related to significant environmental aspects; 3) specific environmental goals and tasks; 4) specific operational criteria; 5) procedures for identifying significant environmental aspects; 6) informing suppliers and contractors about ISO 14001: 2015 procedures and applicable requirements. The entrepreneur must implement a number of procedures relating to: a) identifying and responding to potential emergency events that may have an impact on the environment; b) responding to accidents and preventing or reducing the related negative impacts on the environment; (c) regularly monitoring and measuring the characteristics of the operations which may have a significant effect on the environment; d) corrective and preventive actions; e) identify, store, secure, retrieve and preserve ISO 14001: 2015 records; f) internal auditing; (g) identification of environmental aspects related to activities, products and services; $h$ ) identifying and having access to legal and other requirements to which the organization has committed itself. In addition, an inventory of documented environmental objectives and tasks and environmental programs should be drawn up, the role, responsibilities and authority, training program, internal communication and sharing information on significant environmental aspects should be specified in ISO14001: 2015. After a positive result of the certification audit, a certificate is issued. It is valid for 3 years, provided that annual surveillance audits are carried out to ensure the continued effectiveness of the management system ${ }^{40}$.

Italy is one of the leaders in the implementation of ISO 14001: 2015. This standard defines standard requirements for environmental management systems. In this country, the new edition of ISO 14001 focuses in particular on the "Life Cycle" for management system certification, taking

and of the Council of 16 September 2009 on substances that deplete the ozone layer (OJ L 286, 31.10.2009, p. 1-30).

40 PN-EN ISO 14001: 2015-09 "Environmental management systems - Requirements and guidelines for use." 
into account the economic, environmental and social impacts associated with product design and development at each stage of the life cycle. The certification process is similar to that in Poland. The certification body is ACCREDIA established in accordance with the EU requirements specified also in the Regulation EC 765/2008 requires every member state to nominate a national Accreditation Body and it has granted, for the first time, a legal status to this activity, recognizing it as an expression of public authority. Certification ensures high quality of products, services and environmental management systems and all applicable regulations. With regard to ISO 14001: 2015, special attention is paid to the continuous improvement of the environmental performance of the organization itself. A novelty compared to the previous edition of the standard is the establishment of an organization to analyze the "causes" that affect its ability to achieve what has been agreed. Some of these reasons certainly include environmental conditions and their changes, but the technological, financial, political, social context also needs to be taken into account ${ }^{41}$. An important goal that must be achieved by the organization is the compliance of its activities with environmental policy, pollution prevention; the use of processes, practices, techniques, materials, products, services or energy that must be avoided, limited or controlled (separately or in combination); reducing the emission or discharge of any kind of pollutant or waste in order to reduce the negative impact on the environment; respecting compliance obligations, legal and other requirements that the organization must or will choose to fulfill ${ }^{42}$. Implementation of ISO 14001: 2015 requires compliance with the catalog of legal regulations in the field of environmental protection in the country. In Italy the key environmental legislation is Legislative Decree no. 152/2006, the Environmental Consolidated Act (ECA) (Norme in materia ambientale or Codice dell' Ambiente), including the following aspects: Environmental general principles, Envi-

41 "Mapping ISO 14001:2015 and ISO 14001:2004, For more information about ISO 14001:2015 and related standards," accessed October 6, 2020, https://committee.iso. org/tc207sc1.

42 “Terms and definition in ISO 14001:2015 - where did they originate from?” ISO TC 207 SC1 information note September 2015, Annex SL version May 2015 refers to Annex SL of the Consolidated ISO Supplement to the ISO/IEC Directives, Part 1, 6th edition, published May 1, 2015. 
ronmental Impact Assessment (EIA) and Integrated Pollution Prevention and Control (IPPC) permit, Water resources management and soil protection, Waste and packaging management, Remediation of contaminated sites, Air protection and air emissions, and Environmental damage. There are separate environmental laws regulating specific areas, for example: Presidential Decree no. 59/2013: Single Environmental Authorisation (autorizzazione unica ambientale) (AUA), Legislative Decree no. 49/2014: waste electrical and electronic equipment (WEEE), Legislative Decree no. 166/2010: ambient air quality and Legislative Decree no. 188/2008: waste batteries and accumulators (WBA) and others ${ }^{43}$. The high efficiency of the implementation of ISO 14001: 2015 resulted from the setting of strict time regimes by the accreditation body. The companies carried out this adaptation process with the support of accredited bodies, which had to plan verification for the first certification, supervision or renewal only in accordance with the new standards a few months after the announcement of the new edition of the standard. A few months before the deadline for implementing this standard, the certified companies transition to new standards was 93\% for ISO 14001: $2015^{44}$.

\section{EFFECT OF ISO 14001 IMPLEMENTATION ON THE STATE OF THE ENVIRONMENT IN THE EU}

Sustainable development is the fundamental EU legal principle in environmental protection. This provides a practical guideline for companies in setting environmental goals. However, the functioning of companies based on ensuring this principle and the related removal of existing negative effects on environmental quality requires multiple actions. The legislation at European community level already encourages organizations to participate in eco-management and auditing and to implement stringent

43 Eva Maschietto, and Maggiore Besseghini, "Environmental law and practice in Italy: overview," Practical Law, Law stated as at July 1, 2020, Thomson Reuters, accessed October 10, 2020, https://uk.practicallaw.thomsonreuters.com/1-503-2608? transitionType $=$ Default $\&$ contextData $=($ sc. Default $) \&$ firstPage $=$ true .

44 ACCREDIA, "The Italian Accreditation Body," accessed October 10, 2020, https://www.accredia.it/en/. 
environmental indicators that validate their environmental and sustainable development reports ${ }^{45}$.

Company ISO 14001 efficiency in improving environmental performance has four components: "better compliance with regulations, better management of environmental impact, reduced environmental risk and reduced pollution" 46 . Authors confirm that ISO certification provides improved environmental outcomes. However, the standard establishes only obligation to comply with applicable regulations and does not identify environmental performance in the certification process. The compliance noted with environmental protection regulations indicates appropriate organization adaptation to ongoing change in environmental protection requirements ${ }^{47}$.

European Union Regulation 1221/2009 obliges organizations to report environmental performance using key efficiency indicators (KPIs) for relevant environmental aspects. The parliament considers that the following aspects have significant negative environmental impact; hazardous and non-hazardous waste production, building cleaning and maintenance, electricity and water consumption and the transport of people and goods. The EU environmental policy reflects the vision of the ISO 14001 environmental systems and considers the main problems and environmental goals. It also provides a framework for setting and reviewing the environmental goals that organizations must adopt. These should then be adapted to the nature, scale and impact of their activities, products and services

45 Communication from the Commission to the European Parliament and the Council, Strategy for the sustainable competitiveness of the construction sector and its enterprises, COM/2012/0433 final */Brussels, July 31, $2012 \operatorname{COM(2012)~} 433$ final; European Commission, Commission Staff Working Document, Corporate Social Responsibility, Responsible Business Conduct, and Business \& Human Rights: Overview of Progress, Brussels, 20.3.2019 SWD(2019) 143 final.

46 Magali A. Delmas, Government credible commitment and investment in environmental management standards ISO 14001 in Europe and in the United States (Santa Barbara, Bren School of Environmental Science and Management University of California, 2003).

47 Janusz Myszczyn, "The environmental management systems as a opportunity in promoting sustainable development with special emphasis on the community eco-management and audit scheme (EMAS)," Folia Pomeranae Universitatis Technologiae Stetinensis, Oeconomica 333(86)1 (2017): 68, http://doi.org/ 10.21005/oe.2017.86.1.07. 
that affect the environment ${ }^{48}$. This policy includes the commitment to continuously improve these systems, to prevent pollution and to comply with all relevant legal requirements. To help ensure these outcomes, the 2017 Annex III Action Plan was adopted by the Environmental Management Steering Committee on the 9th of December 2016. An example of the required Key Environmental Performance Indicators (KPIs), established by the European Parliament and the organization's results achieved after the implementation of ISO 14001 in 2012-2016: (1) $\mathrm{CO}_{2}$ emission was to be reduced by $27.3 \%$; (2) electricity consumption reduction by $4 \%$ from 12.4\% between 2012 and 2016; and the EU Parliament's 4\% target was vastly exceeded; (3) gas, heating oil and district heating consumption reduction by 5\% between 2012 and 2016; (4) the quantity of office and kitchen waste decreased by $28.62 \%$ during the monitored period, significantly exceeding the 5\% target, and (5) annual waste recycling objective was $68 \%$ in 2016; although the $65.8 \%$ recycling recorded in 2016 is just below the $68 \%$ objective, this was exceeded in 2014 with $68.9 \%$ and in 2015 with $77.4 \%{ }^{49}$. The European Environment Agency (EEA) is an agency of the European Union established by Council Regulation (EEC) No $1210 / 90^{50}$, which established the European Environment Information and Observation Network (EIONET). One of the main tasks of the EEA under this mandate is to publish a report on the state of the environment, trends in environmental change and related prospects every 5 years. Based

48 European Commission, Commission Decision (EU) 2017/2285 of 6 December 2017 Amending the user's guide setting out the steps needed to participate in EMAS, under Regulation (EC) 1221/2009 of the European Parliament and of the Council on the voluntary participation by organisations in a Community eco-management and audit scheme (EMAS) (notified under document C(2017) 8072) (OJ L 328/38, 12.12.2017).

49 Report of the European Parliament Environmental Statement for 2016, pursuant to Annex IV to Regulation (EC) 1221/2009 of the European Parliament and of the Council of 25 November 2009 on the voluntary participation by organisations in a Community eco-management and audit scheme (EMAS), repealing Regulation (EC) 761/2001 and Commission Decisions 2001/681/EC and 2006/193/EC. Adopted by the Steering Committee for Environmental Management Verified by on June 20-29, 2017 on September 26, 2017.

50 Council Regulation (EEC) No 1210/90 of 7 May 1990 on the establishment of the European Environment Agency and the European Environment Information and Observation Network (OJ L 120, 11.5.1990, p. 1-6). 
on the analysis of data from this institution, in Italy in 1990-2018 there was a decrease in greenhouse gas emission by $11.4 \%$ and in Poland by $10.7 \% \%^{51}$. In 2017, in terms of energy consumption in Italy, the largest share was recorded for natural gas and oil and petroleum products, and next for renewables and biofuels, while in Poland - for solid fossil fuels, oil and petroleum products and natural gas. The final consumption in comparison with other EU countries at the level in Italy was 180 and in Poland $190 \mathrm{kWh}$ per thousand EUR. The circular material use rate in 2010-2016 in Italy increased from 11 to $17.2 \%$, and in Poland it was constant at $10.2 \%$. Domestic material waste production in 2018 in Italy was 8 and in Poland 20 tonnes per capita. In addition, the highest waste treatment recycling rate in the EU was recorded for Italy at $78.9 \%$ with landfills at $14 \%$ while in Poland at an average level of $46.2 \%$ with landfills $28 \%{ }^{52}$. Therefore, the implementation of the ISO standard in more organizations can be associated with an increase in environmental quality indicators in a given country, as can be seen in the case of Italy, which achieves higher greenhouse gas reduction rates, lower energy consumption and waste production, and the highest in Europe regarding waste recycling.

\section{CONCLUSIONS}

The ISO 14001 environmental management system standard is an instrument of international environmental protection law introduced by sof law regulations. It is a voluntary system that does not constitute a part of any legal order, however it is legally enforced because it is introduced by normative acts of international environmental law ${ }^{53}$. The benefits to be derived from the ISO 14001 international standard are increasingly

51 EUROSTAT, "European Environmental Agency, Greenhouse gas emission statistics - emission inventories," accessed October 10, 2020, https://ec.europa.eu/eurostat/ statistics-explained/pdfscache/1180.pdf.

52 EUROSTAT, "Energy, transport and environment statistics - 2019 edition," accessed October 10, 2020, https://ec.europa.eu/eurostat/en/web/products-statistical-books/-/ KS-DK-19-001.

53 Tomasz Bojar-Fijałkowski, "System ISO 14001 jako instrument międzynarodowego prawa ochrony środowiska,” 57. 
recognized and welcomed by organizations in European Union countries. The implementation rate is therefore increasing.

Available literature gives four reasons why every organization should consider environmental factors in its management processes (1) organizations must be ethical because they have a duty of care for the earth, their employees, customers and all living things. For example, ISO 14001 and similar standards will prevent firms giving employees silicosis in the future and limit smog that sometimes hides the sky, (2) economic forces today demand preserving precious resources, generating less waste and dangerous substances and using less energy. All these measures will reduce costs and the likelihood of sanctions, (3) all organizations are facing increased legal obligations as governments are now forced to step in and counteract past environmental disasters and (4) commercial interests will continue to drive organizations to be more competitive ${ }^{54}$. Acceptance of ISO 14001 principles forces organizations to bear the costs of certification and also those associated with changing management structure and implementing environmentally friendly procedures. These involve at least reducing harmful emissions, remediation of previous environmental damage and ensuring safe future emissions, waste disposal and water and sewage management ${ }^{55}$.

The procedures for the implementation of ISO 14001 must comply with the regulations and guidelines set out in EU Regulations 761/2001 and 1221/2009 and national legislation on certification, and most importantly, the activities of the organization applying for the certificate must comply with national legislation on environmental protection. The implementation of the ISO 14001 standard requires a procedure and certification by a legally authorized accreditation body. Enterprises have been obliged to implement the new edition of the ISO 14001: 2015 standard within

54 Alina Matuszak-Flejszman, "Benefits of Environmental Management System in Polish Companies Compliant with ISO 14001," Polish Journal of Environmental Studies 18(3) (2009): 413.

55 Urszula Szymańska, and Ewa Mikołajczak, "Międzynarodowa norma ISO 14001 w procesie zarządzania zasobami środowiska," Ochrona Środowiska 2 (2001): 25; Elżbieta Zębek, "Obowiązki i działania przedsiębiorstw w zakresie ochrony środowiska przed odpadami niebezpiecznymi," in Prawo ochrony środowiska jako warunek prowadzenia dziatalności gospodarczej, ed. Janina Ciechanowicz-McLean, and Tomasz Bojar-Fijałkowski (Gdańsk: Wydawnictwo Uniwersytetu Gdańskiego, 2009), 118. 
3 years. The key change in the new edition is the inclusion of the risk management requirement in the environmental management system, which will undoubtedly improve the effectiveness of environmental protection. When analyzing the implementation process of this environmental standard in Poland and Italy, it can be concluded that the procedures are similar to the international ISO standards specified in national documents. However, a slightly different approach was noted in implementing ISO 14001: 2015. In Poland, the risk assessment for all elements of the environment has been taken into account in detail, while in Italy the new edition of ISO 14001 focuses in particular on the "Life Cycle" for management system certification, taking into account the economic, environmental and social impacts associated with product design and development at every stage life cycle. The main task is to set up an organization to analyze the "causes" that affect its ability to achieve what has been previously determined. Thus, here is a broader approach to the analysis of the causes, which includes not only environmental conditions and their changes, but also the technological, financial, political and social context. In addition, special attention is paid to the continuous improvement of the environmental performance of the organization itself. A greater number of legal acts in Poland has also been noticed, and thus greater dispersion of legal regulations in the field of environmental protection, which does not always favor their effective application. The multitude of regulations in Poland, greater than in Italy, does not prove that the implementation of the ISO 14001 system is more effective. The data shows that the accreditation body in Italy imposed greater time regimes for the implementation of the new ISO 14001: 2015 standard and was modeled directly on the international (Canadian) guidelines indicated in the ISO 14001: 2015 document package with a commentary on explaining many issues in this regard.

As previously mentioned, immeasurable improvement in environmental quality is more important than measurable economic benefits. Sustainable development aids in ensuring a clean environment which is essential for all life, including present and future human generations. In addition, although economic viability necessitates the use of environmental resources, observation of the principles of environmental law, as ISO 14001, maintains precautionary and preventative emission reduction targets. In conclusion, the ISO 14001 management system provides an excellent 
instrument for environmental quality improvement and it also supports the principle of "polluter pays". Evidence of ISO 14001 worth is proven herein by the increase in the number of European Union organizations which have decided to implement this environmental management system. Finally, this ISO 14001 uptake correlates with the enhanced environmental quality witnessed in the decreased noxious gas emissions and increased waste recycling which are improving our air, soil and water quality. Based on the data on Environmental Performance Indicators in the analyzed countries in the years after the implementation of ISO 14001, it is possible to link the implementation of the standard in a larger number of organizations with an increase in environmental quality indicators in a given country, which can be seen in the case of Italy, which achieves higher greenhouse gas reduction indicators, lower consumption of energy and less waste production, and the highest in Europe for waste recycling. Therefore, a postulate arises here, in order to achieve an improvement in the quality of the environment in the EU, enterprises should be supported through simpler procedures for the implementation of environmental standards and encouraged by the introduction of more encouraging legal and administrative instruments.

\section{REFERENCES}

Abraham, Martin. Sustainable Technologies. Amsterdam: Elsevier, 2017.

Balan, George, and Dragolea Laris. "Implementation of environmental management systems - ISO 14001 or EMAS." Academic Research International, no. 4(3) (2013).

Bojar-Fijałkowski, Tomasz. "Wykonanie Rozporządzenia (WE) 761/2001 przez organy administracji publicznej w Polsce." In Finansowanie zadań administracji publicznej ze środków UE, edited by Marcin Szewczak, and Małgorzata Ganczar, 9-20. Lublin: Wydawnictwo KUL, 2001.

Bojar-Fijałkowski, Tomasz. "System ISO 14001 jako instrument międzynarodowego prawa ochrony środowiska." Europejski Przeglad Prawa i Stosunków Międzynarodowych, no. 4(19) (2011): 48-65.

Bojar-Fijałkowski, Tomasz. "Ocena skuteczności zarządzania środowiskowego jako instrumentu prawa ochrony środowiska na przykładzie EMAS.” In Dekada 
harmonizacji w prawie ochrony środowiska, edited by Maciej Rudnicki, Anna Haładyj, and Kamila Sobieraj, 219-240. Lublin: Wydawnictwo KUL, 2011. Bojar-Fijałkowski, Tomasz. "Elementy zarządzania jakością i zarządzania środowiskowego wspomagające nowe zarządzanie publiczne w administracji." In Pomiędzy zarządzaniem publicznym a ogólna teoria administracji, edited by Ewa Jasiuk, Gerard P. Maj, Kamil Sikora, and Stanisław Wrzosek, 127-144. Radom: Wydawnictwo WSH, 2013.

Bojar-Fijałkowski, Tomasz. "Nauka o zarządzaniu w gospodarczym prawie ochrony środowiska - analiza wybranych pojęć." In Zasada zrównoważonego rozwoju w wymiarze gospodarczym i ekonomicznych, edited by Bartosz Rakoczy, Karolina Karpus, Małgorzata Szalewska, and Martyna Walas, 199-210. Toruń: Wydawnictwo UMK, 2015.

Bojar-Fijałkowski, Tomasz. "Odpowiedzialność prawna organizacji z certyfikowanym systemem EMAS.” In Odpowiedzialność za środowisko w ujęciu normatywnym, edited by Elżbieta Zębek, and Michał Hejbudzki, 235-250. Olsztyn: Wydawnictwo UWM, 2017.

Bukowski, Zbigniew. Prawo międzynarodowe a ochrona środowiska. Toruń: Dom Organizatora, 2005.

Ciechanowicz, Janina. Międzynarodowe prawo ochrony środowiska. Warsaw: PWN, 1999.

Ciechanowicz-McLean, Janina. Ochrona środowiska w dziatalności gospodarczej. Warsaw: LexisNexis, 2003.

Ciechanowicz-McLean, Janina, and Tomasz Bojar-Fijałkowski, ed. Gospodarcze prawo środowiska. Gdańsk: Wydawnictwo UG, 2009.

Ciechanowicz-McLean, Janina. Prawo ochrony $i$ zarządzania środowiskiem. 2nd ed. Warsaw: Difin, 2019.

Ciravegna, Luis M., and Martins da Fonseca. "ISO 14001:2015: An Improved Tool for Sustainability." Journal of Industrial Engineering and Management, no. 8(1) (2015). http://dx.doi.org/10.3926/jiem.1298.

Delmas, Magali A. Government credible commitment and investment in environmental management standards ISO 14001 in Europe and in the United States. Santa Barbara: Bren School of Environmental Science and Management University of California, 2003.

Farmer, Alfred M., ed. Manual of European Environmental Policy. London: Routledge, 2012.

Heras-Saizarbitoria Inaki, ed., ISO 9001, ISO 14001, and New Management Standards.

Cham: Springer International Publishing, 2018. https://doi.org/10.1007/978-3319-5675-5. 
Jabłońska-Bonca, Jolanta. Wstęp do nauk prawnych. Poznań: Ars Boni Et Aequi, 1996. Kenig-Witkowska, Maria M. Prawo środowiska Unii Europejskiej. Warsaw: Lex a Wolters Kluwer business, 2012.

Kivi, Krislin, and Natalja Gurvits. "Eco-Management and Audit Scheme (EMAS) implementation in the European Union: survey of Estonian certified organisations." European Integration Studies, no. 11 (2017): 211-219. http://10.5755/j01.eis.0.11.17982.

Larsson, Stefan. ISO 14001:2015, Six Dimensions of Sustainability. 2015. http:/ artykuł\%20EMAs/normy\%20EMAS\%20i\%20ISO/2015-12-02-StefanLarsson.pdf.

Maschietto, Eva, and Maggiore Besseghini. Environmental law and practice in Italy: overview, Practical Law, Law stated as at July, 1, 2020. Thomson Reuters, 2020. https://uk.practicallaw.thomsonreuters.com/1-503-2608? transitionType $=$ Default $\&$ context Data $=($ sc. Default $) \&$ firstPage $=$ true .

Matuszak-Flejszman, Alina. "Benefits of Environmental Management System in Polish Companies Compliant with ISO 14001.” Polish Journal of Environmental Studies, no. 18(3) (2009).

McCreary, James H. "ISO 14001 A framework for coordinating existing environmental management responsibilities." CIM Bulletin, no. 89 (1996).

Murray, Paula C. "The international environmental management standard, ISO 14000: a non-tariff barrier or a step to an emerging global environmental policy?." Penn Law: Legal Scholarship Repository, no. 18(2) (2014): 577-615.

Myszczyn, Janusz. "The environmental management systems as a opportunity in promoting sustainable development with special emphasis on the community eco-management and audit scheme (EMAS)." Folia Pomeranae Universitatis Technologiae Stetinensis, Oeconomica, no. 333(86)1 (2017): 63-78. http://doi. org/10.21005/oe. 2017.86.1.07.

Pachura, Piotr, and Agnieszka Ociepa-Kubicka. "Management and audit scheme (EMAS) functioning on the example of the water supply and sewerage joint stock company of the Częstochowa District." Polish Journal of Management Studies, no. 10(2) (2014): 143-150.

Psomas, Evangelos, Christos V. Fotopoulos, and Dimitrios P. Kafetzopoulos. "Motives, difficulties and benefits in implementing the ISO 14001 Environmental Management System." Management of Environmental Quality An International Journal, no. 22(4) (2011). http://doi.org/10.1108/14777831111136090.

Szymańska, Urszula, and Ewa Mikołajczak. "Międzynarodowa norma ISO 14001 w procesie zarządzania zasobami środowiska." Ochrona Środowiska, no. 2 (2001): 21-27. 
Testa, Francesco, Fabio Iraldo, and Tiberio Daddi. “The Effectiveness of EMAS as a Management Tool: A Key Role for the Internalization of Environmental Practices." Organization \& Environment, no. 31(1) (2017): 48-69. http://doi. org/10.1177 \%2F10860 26616687609.

Tourais, Patricia, and Nuno Videira. "Why, How and What do Organizations Achieve with the Implementation of Environmental Management Systems? - Lessons from a Comprehensive Review on the Eco-Management and Audit Scheme." Sustainability, no. 8(3) (2016): 283. http://doi.org/10.3390/ su8030283.

Vomero, Reisa Aline, Fabio de Oliveira Nevesa, Suzana Eda Hikichia, Eduardo Gomes Salgadoa, and Luiz Alberto Beijoa. "Is ISO 14001 certification really good to the company? a critical analysis." Production Systematic Review, no. 28 (2018). https://doi.org/10.1590 /0103-6513.20180073.

Wilson, Raymond C. "What you don't know can definitely hurt you." Pollution Engineering, no. 30(12) (1998): 33-34.

Zębek, Elżbieta. "Obowiązki i działania przedsiębiorstw w zakresie ochrony środowiska przed odpadami niebezpiecznymi." In Prawo ochrony środowiska jako warunek prowadzenia dziatalności gospodarczej, edited by Janina Ciechanowicz-McLean, and Tomasz Bojar-Fijałkowski, 113-120. Gdańsk: Wydawnictwo Uniwersytetu Gdańskiego, 2009. 